\title{
Teaching NeuroImages: Radiologic features of septo-optic dysplasia plus syndrome
}

Mario Ganau, MD, PhD, Giacomo Talenti, MD, and Felice D'Arco, MD

Neurology ${ }^{\circledR} 2018 ; 91:$ e2200-e2201. doi:10.1212/WNL.0000000000006631

Correspondence

Dr. Ganau

mario.ganau@

alumni.harvard.edu

\section{Figure MRI brain}
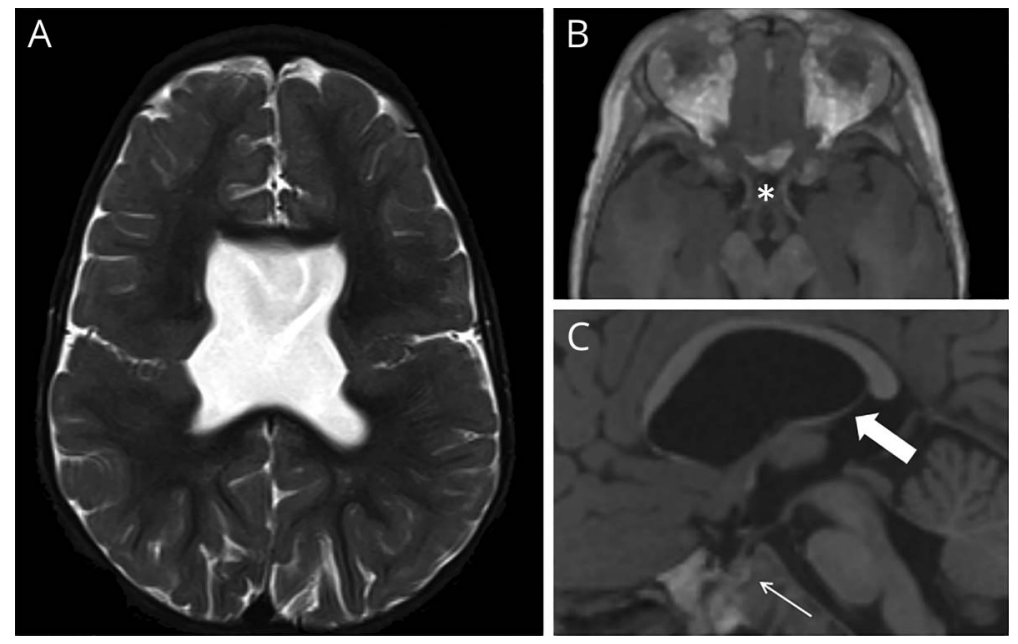

(A and B) T2/T1-weighted axial views. (C) T1-weighted sagittal views.Multiple intracranial abnormalities are identified: (A) absent septum pellucidum and bilateral closed-lips schizencephaly; (B) achiasmia (asterisk); (C) pituitary hypoplasia (thin arrow), horizontal course of the fornix (thick arrow), and hypoplastic genu and splenium of corpus callosum.

A 17-month-old boy showing features of global developmental delay and visual impairment, despite physiologic head circumference growth (between the 50th and 85th centile), was admitted for investigations. On examination, he appeared alert, with pale optic discs, horizontal jerk nystagmus, spasticity, and small genitalia.

MRI brain (figure) excluded hydrocephalus, demonstrating instead hallmarks of neuronal migration disorder. ${ }^{1}$ Besides schizencephaly, multiple midline abnormalities were noticed, such as optic nerve hypoplasia and achiasmia (deficient chiasmal decussation), pituitary hypoplasia, and absence of septum pellucidum. ${ }^{1,2}$ Hormonal tests demonstrated panhypopituitarism; hence care was transferred to the septo-optic dysplasia (SOD) multidisciplinary group for management of SOD plus syndrome. ${ }^{1}$

\section{Author contributions}

M. Ganau: study concept and design. M. Ganau and Dr. Talenti: analysis and interpretation. Dr. D'Arco: acquisition of data, critical revision of the manuscript, study supervision.

\section{MORE ONLINE}

$\rightarrow$ Teaching slides

links.lww.com/WNL/ A755

From the Department of Neurosurgery (M.G.), Oxford University Hospitals, UK; Department of Diagnostics and Pathology (G.T.), Verona University Hospital, Italy; and Department of Neuroradiology (F.D.), Great Ormond Street Hospital For Children, London, UK.

Go to Neurology.org/N for full disclosures. Funding information and disclosures deemed relevant by the authors, if any, are provided at the end of the article. 


\section{Study funding}

No targeted funding reported.

\section{Disclosure}

The authors report no disclosures relevant to this manuscript. Go to Neurology.org/ $\mathrm{N}$ for full disclosures.

\section{References}

1. Miller SP, Shevell MI, Patenaude Y, Poulin C, O'Gorman AM. Septo-optic dysplasia plus: a spectrum of malformations of cortical development. Neurology 2000;54: 1701-1703.

2. Sami DA, Saunders D. The achiasmia spectrum: congenitally reduced chiasmal decussation. Br J Ophthalmol 2005;89:1311-1317. 


\section{Neurology}

Teaching NeuroImages: Radiologic features of septo-optic dysplasia plus syndrome

Mario Ganau, Giacomo Talenti and Felice D'Arco

Neurology 2018;91;e2200-e2201

DOI 10.1212/WNL.0000000000006631

This information is current as of December 3, 2018

\section{Updated Information \&} Services

References

Subspecialty Collections

Permissions \& Licensing

Reprints including high resolution figures, can be found at: http://n.neurology.org/content/91/23/e2200.full

This article cites 2 articles, 1 of which you can access for free at: http://n.neurology.org/content/91/23/e2200.full\#ref-list-1

This article, along with others on similar topics, appears in the following collection(s):

Developmental disorders

http://n.neurology.org/cgi/collection/developmental_disorders MRI

http://n.neurology.org/cgi/collection/mri

Information about reproducing this article in parts (figures,tables) or in its entirety can be found online at:

http://www.neurology.org/about/about_the_journal\#permissions

Information about ordering reprints can be found online:

http://n.neurology.org/subscribers/advertise

Neurology ${ }^{\circledR}$ is the official journal of the American Academy of Neurology. Published continuously since 1951, it is now a weekly with 48 issues per year. Copyright () 2018 American Academy of Neurology. All rights reserved. Print ISSN: 0028-3878. Online ISSN: 1526-632X.

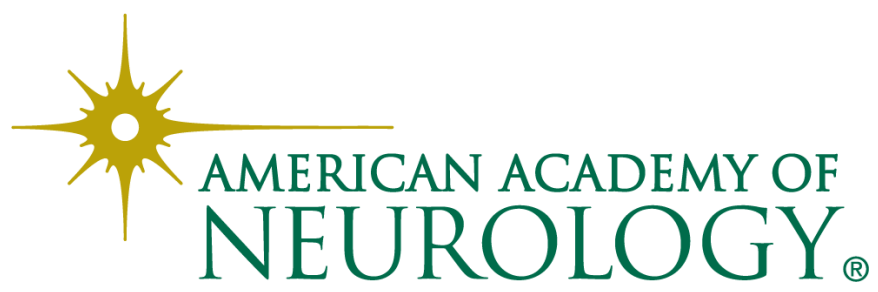

